\title{
Partial Characterization of Protease from the Leaves of Jatropha
}

\section{curcas}

\author{
M. A. Ibrahim ${ }^{1}$, J. O. Olatominwa ${ }^{1}$, A. B. Aliyu ${ }^{2}$, M. Bashir ${ }^{1} \&$ A. B. Sallau ${ }^{1}$ \\ ${ }^{1}$ Department of Biochemistry, Ahmadu Bello University, Zaria, Nigeria \\ ${ }^{2}$ Department of Chemistry, Ahmadu Bello University, Zaria, Nigeria \\ Correspondence: M. A. Ibrahim, Department of Biochemistry, Ahmadu Bello University, Zaria, Nigeria. Tel: \\ 234-703-110-4932. E mail: mauwalibrahim@gmail.com, maibrahim@abu.edu.ng
}

\author{
Received: May 31, 2012 Accepted: July 18, 2012 Online Published: September 21, 2012 \\ doi:10.5539/ijb.v4n4p79 URL: http://dx.doi.org/10.5539/ijb.v4n4p79
}

\begin{abstract}
The crucial roles of proteases in food and other industries stimulate research to find additional sources of the enzyme especially from non-conventional sources. In this study, protease was partially characterized from Jatropha curcas leaves. The enzyme had $\mathrm{pH}$ and temperature optima of 4.0 and $45^{\circ} \mathrm{C}$ respectively. A decline in residual activity of the enzyme was observed at above $45^{\circ} \mathrm{C}$ and the activation energy (Ea) from Arrhenius plot was $0.57 \mathrm{~kJ} / \mathrm{mol}$. The enzyme showed specificity in the order; casein $>$ hemoglobin $>$ albumin $>$ ovalbumin. Initial velocity studies for the determination of kinetic parameters revealed a $K_{M}$ and $V_{\max }$ of $0.48 \mathrm{mg} / \mathrm{ml}$ and $0.014 \mu \mathrm{mol} / \mathrm{min}$ respectively with a computed index of physiological efficiency $\left(K_{\text {cat }}\right)$ of $0.029 \mathrm{~min}^{-1}$. Furthermore, Dixon-Webb's plot identified ionizable groups at the active site with $\mathrm{pKa}_{1}$ and $\mathrm{pKa}_{2}$ of 5.0 and 5.3 respectively as well as an enthalpy of ionization of $0.047 \mathrm{kcal} / \mathrm{mol}$ implicating aspartate as an important amino acid at the active site of the enzyme. The protease was highly sensitive to cysteine protease specific inhibitor iodoacetate while 1,10phenanthroline and ethylenediaminetetraacetate slightly inhibited the enzyme. Data from this study suggest that $J$. curcas protease possesses closely similar properties to other known industrial proteases.
\end{abstract}

Keywords: enzyme kinetics, industrial process, Jatropha curcas, protease

\section{Introduction}

Enzymes have evolved to become an integral part of many industrial processes and among the different classes of enzymes, proteases constitute $60 \%$ of the total worldwide sale of enzymes used in various industries and also account for at least a quarter of the total global enzyme production (Gupta, Beg, \& Lorenz, 2002). Proteases have important industrial applications which include detergent, food, leather and meat tenderization industries (Cheng, Lu, Li, Liu, \& Liang, 2010). They are also important tools in studying the structure of proteins and peptides. Furthermore, these enzymes are used in pharmaceuticals, medical diagnosis, and decomposition of gelatin on X-ray films as well as in textiles (Tunga, Shrivastava, \& Banerjee, 2003). Although most available reports on proteases are derived from microbial origin (Tang et al., 2003; Soares, Castilho, Bon, \& Freire, 2004; Ire, Okolo, \& Moneke, 2011) but commercial use of proteases with different origins for hydrolysis of proteins was reported to be very promising due to the biological origin of enzymes (Capiralla, Hiroi, Hirokawa, \& Maeda, 2002). Plant cysteine proteases suchas papain and stem bromelain are still extensively used for medicine, brewing wine, and food industry (Kaneda, Yonezawa, \& Uchikoba, 1997). Thus, plant proteases with important industrial applications have also been characterized (Fahmy, Ali, \& Mohamed, 2004; Yang, Song, Gu, \& Li, 2011).

Jatropha curcas is an arid plant belonging to the family Euphorbiaceae and is common in most arid areas of Asia, South America and Africa. The plant is a common shrub of 3-6 m and the leaves are medicinally used as remedy against rheumatism and jaundice. The seeds are rich sources of oil and the oil obtained from the seeds is used up in the soap industry and also as source of energy (Subramani, Chandrashekharaiah, Swamy, \& Murthy, 2012). The plant has attained economical importance due to these applications in areas with extreme climates and soil conditions because of its extraordinary high drought resistance (Gubitz, Lischnig, Stebbing, \& Saddler, 1997). However, in many parts of the world including ours, the plant is still merely used as live fence and for erosion control. In order to exploit more commercial potentials of this plant and search for more sources of plant proteases, the present work was undertaken to partially characterize protease from the leaves of the plant with a 
view to obtain preliminary kinetic data for the enzyme which could be useful in assessing its overall suitability in industrial processes.

\section{Materials and Methods}

\subsection{Plant Material}

Jatropha curcas fresh leaves was collected from Zango village, Zaria, Kaduna state, Nigeria and was identified to the species level at the herbarium unit of the Biological Sciences Department, Ahmadu Bello University Zaria-Nigeria where a voucher specimen (No. 1911) was deposited. The leaves were thoroughly washed with five changes of distilled water and refrigerated at $4^{\circ} \mathrm{C}$ until needed.

\subsection{Crude Enzyme Extraction}

The crude enzyme was extracted according to Li, Cao, Gu and Wen (2011) with slight modifications. Briefly, 10 $\mathrm{g}$ of the leaves was homogenized with cold phosphate buffer $\mathrm{pH} 6.8(3 \times 30 \mathrm{ml})$. The homogenate was then filtered with a cheese cloth and centrifuged at $5000 \mathrm{xg}$. The supernatant was collected and kept on ice while the pellet was resuspended in $30 \mathrm{ml}$ of the extraction buffer. This homogenate was similarly treated and the supernatant collected. The combined supernatants were used for the protease activity assay.

\subsection{Protease Assay}

The protease activity was assayed as described by Fahmy et al. (2004). Briefly, $50 \mu 1$ of the crude enzyme source was incubated with $500 \mu 1$ of $100 \mathrm{mM}$ sodium acetate buffer $\mathrm{pH} 4.5$, and $100 \mu 1$ of $3 \%$ casein at $37^{\circ} \mathrm{C}$. The mixture was then made up to $1 \mathrm{ml}$ with distilled water. Assays were carried out after $1 \mathrm{~h}$, the reaction was stopped by the addition of $200 \mu \mathrm{l}$ of $20 \%$ trichloroacetic acid. The precipitated proteins were removed by centrifugation at $10,000 \mathrm{xg}$ and the absorbance of the supernatant was measured at $366 \mathrm{~nm}$. The activity of protease was defined as the amount of enzyme that hydrolyzes $1 \mu \mathrm{mol}$ of amino acids (in terms of tyrosine) from casein per minute under the standard assay conditions.

\section{$2.4 \mathrm{pH}$ and Temperature-dependent Studies}

A pH dependent assay of the enzyme was conducted using $50 \mathrm{mM}$ acetate buffer $\mathrm{pH} 3.0-5.0 ; 50 \mathrm{mM}$ phosphate buffer $\mathrm{pH}$ 6.0-7.0 and $0.1 \mathrm{M}$ TrisHcl buffer $\mathrm{pH}$ 8.0-9.0. The temperature-dependent study was performed by determining the enzyme activity at varying temperatures ranging between 20 and $60^{\circ} \mathrm{C}$. In order to study the thermostability of the enzyme, the enzyme was preincubated at various temperature $\left(20-60^{\circ} \mathrm{C}\right)$ for $1 \mathrm{~h}$ and thereafter the residual activity was assayed. An Arrhenius plot of $\log$ of enzyme activity (Log V) versus reciprocal of absolute temperature $\left(\mathrm{K}^{-1}\right)$ was constructed to determine the activation energy (Ea) of the enzyme.

\subsection{Substrate Specificity and Kinetic Studies}

Substrate specificity studies were carried out using the following substrates; albumin, hemoglobin, casein and ovalbumin. Kinetic experiments were performed using varying concentrations of casein $(0.94-30 \mathrm{mg} / \mathrm{ml})$ and the initial velocity values obtained were used to determine the $\mathrm{K}_{\mathrm{M}}, \mathrm{V}_{\max }$ and hence the computed index of physiological efficiency $\left(K_{c a t}\right)$ of the J.curcas protease from the double reciprocal plot of the data. Furthermore, initial velocity data at varying $\mathrm{pH}$ values (3.0-9.0) was used to construct a Dixon-Webb's plot of $\log$ of $\mathrm{V}_{\max } / \mathrm{K}_{\mathrm{M}}$ against the corresponding $\mathrm{pH}$ values to determine the possible ionizable groups in the active site of the J.curcas protease.

\subsection{Effect of Some Divalent Cations and Some Inhibitors on J. curcas Protease Activity}

The enzyme assay described above was performed in the presence of chloride salts of the following divalent ions; $\mathrm{Ca}^{2+}, \mathrm{Co}^{2+}, \mathrm{Mg}^{2+}, \mathrm{Zn}^{2+}, \mathrm{Fe}^{2+}$ and $\mathrm{Cu}^{2+}$ at $10 \mathrm{mM}$ final concentrations as well as $0.05 \mathrm{M}$ iodoacetate (IAA), 0.05 M 1,10 phenanthroline(PT) and $0.05 \mathrm{M}$ ethylenediaminetetraacetate (EDTA).

\section{Results}

The $\mathrm{pH}$ dependent profile of the $J$. curcas protease revealed an optimum activity at $\mathrm{pH} 4.0$ and relatively lower enzyme activity was observed at alkaline $\mathrm{pH}$ in comparison to acidic $\mathrm{pH}$ values (Figure 1). The temperature dependent studies showed a typical bell shaped curve with optimum activity at $45^{\circ} \mathrm{C}$ (Figure 2). A sharp decline in residual activity of the $J$. curcas protease was observed at above $45^{\circ} \mathrm{C}$ in a heat stability studies (Figure 3) and the Arrhenius plot gave an Ea value of $0.57 \mathrm{~kJ} / \mathrm{mol}$ for the $J$. curcas protease (Figure 4). 


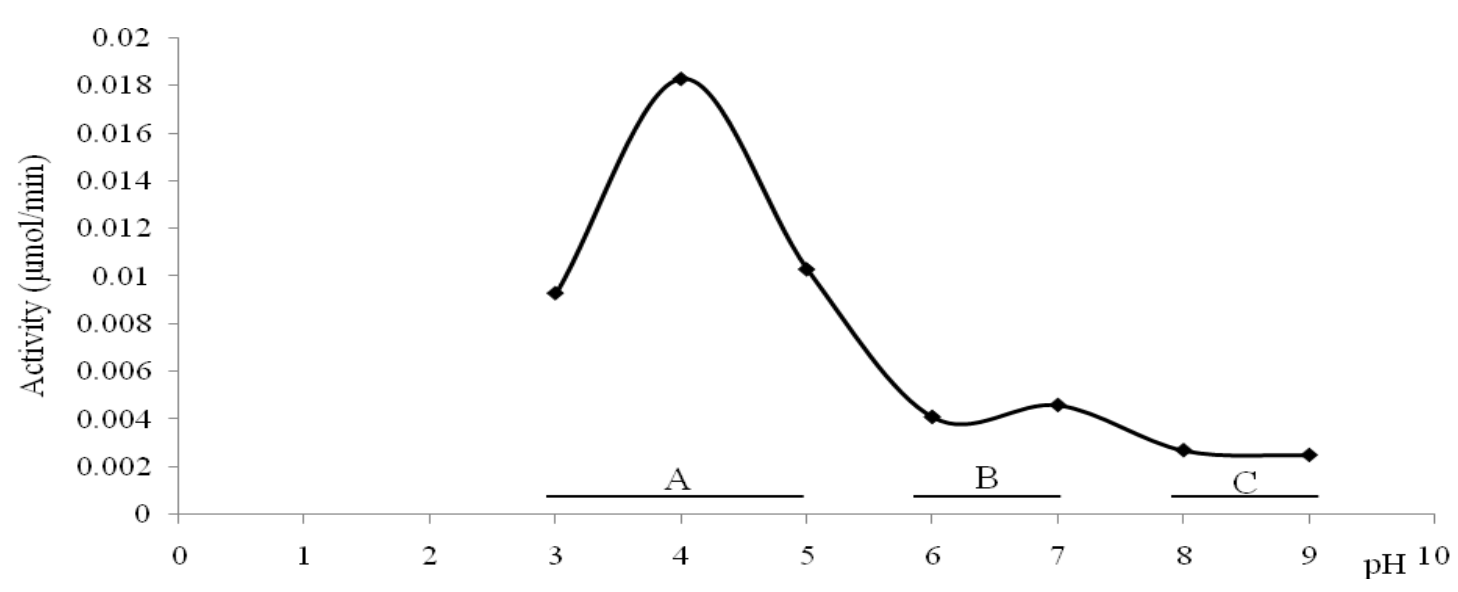

Figure 1. Effect of $\mathrm{pH}$ on the activity of protease from J. curcas protease. The type of buffer used in the region A,

$\mathrm{B}$ and $\mathrm{C}$ are $50 \mathrm{mM}$ acetate buffer, $50 \mathrm{mM}$ phosphate buffer and $0.1 \mathrm{M}$ TrisHcl buffer respectively

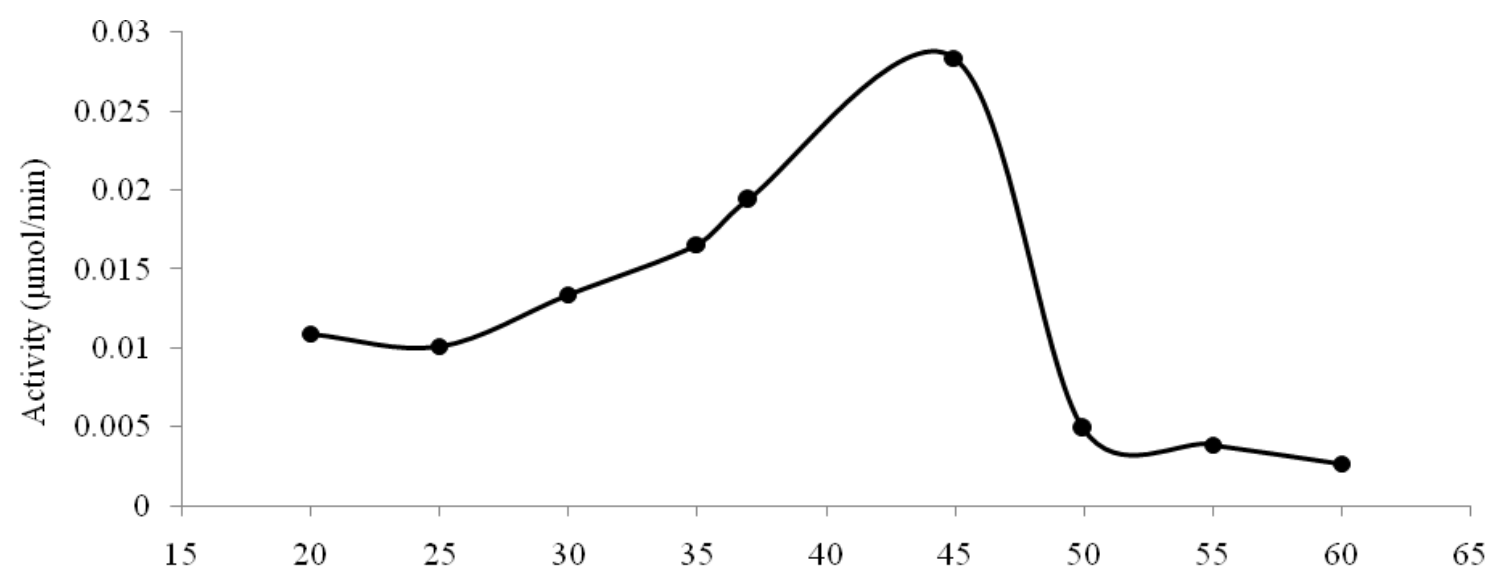

Temperature $\left({ }^{\circ} \mathrm{C}\right)$

Figure 2. Effect of temperature on the activity of J.curcas protease

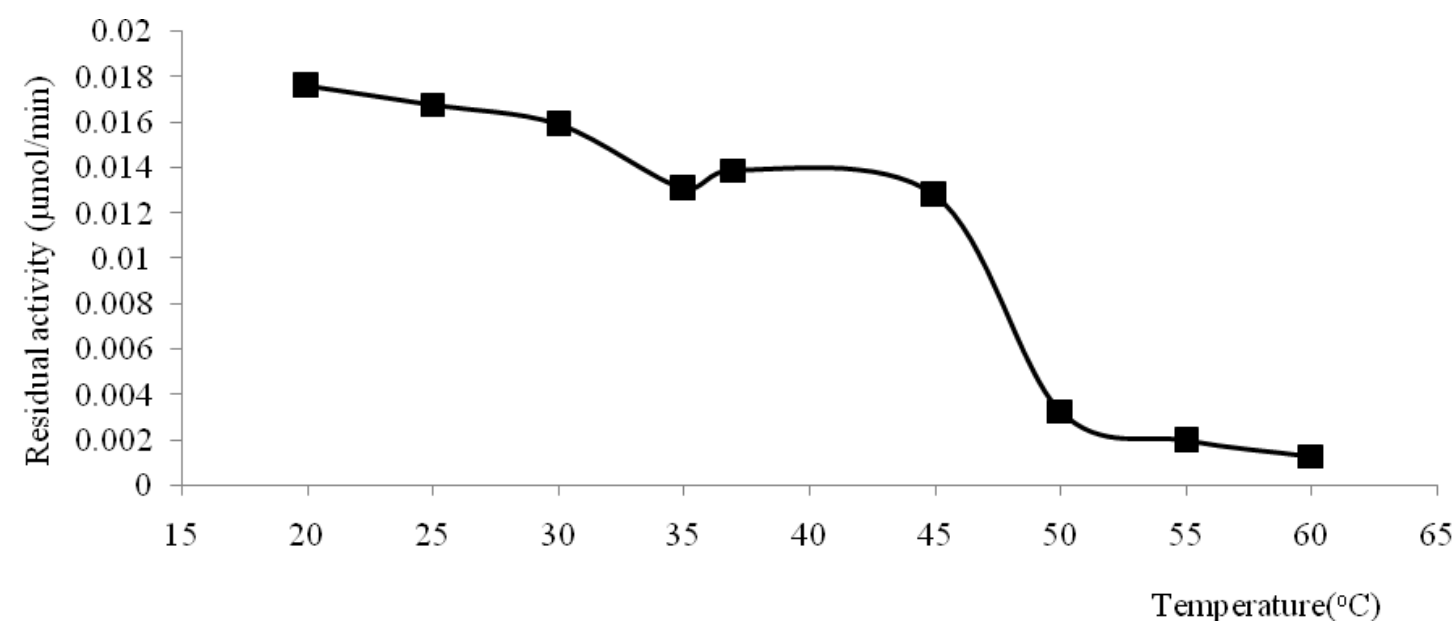

Figure 3. Thermostability profile of protease from J.curcas leaves 


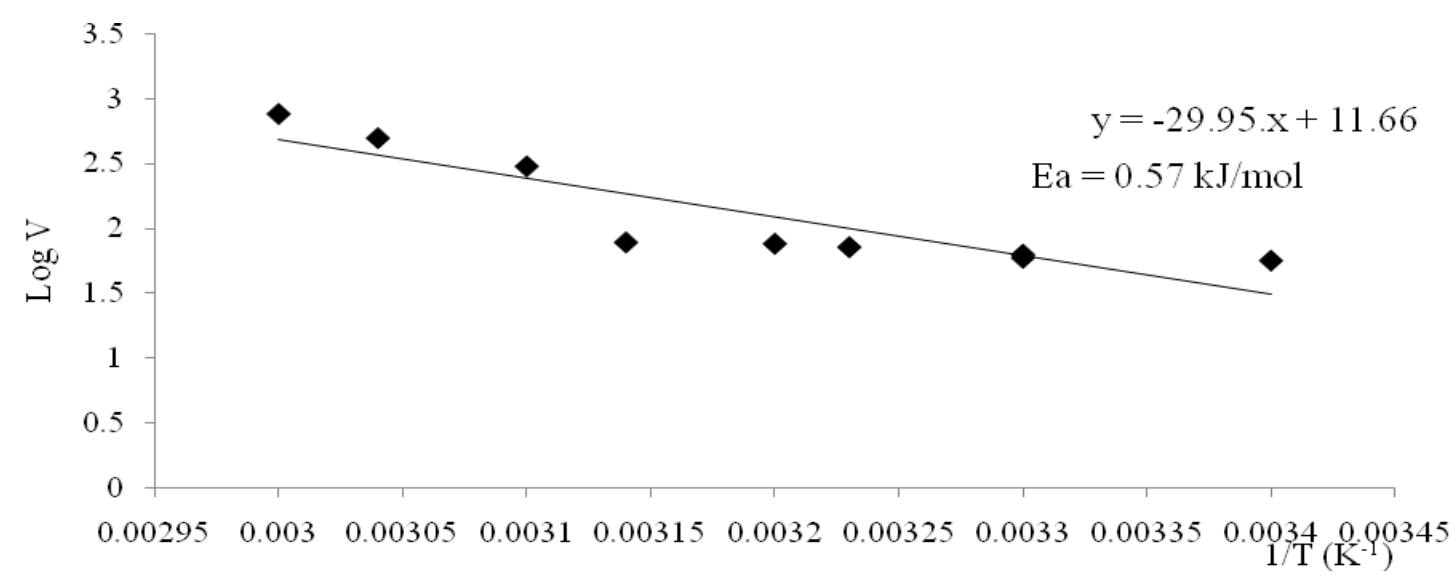

Figure 4. Arrhenious plot for the determination of activation energy for $J$. curcas protease. Each point represents the average of three experiments

The enzyme showed specificity in the order; casein $>$ hemoglobin $>$ albumin $>$ ovalbumin. Steady state kinetic analysis from the initial velocity studies using casein as substrate revealed a $\mathrm{K}_{\mathrm{M}}$ and $\mathrm{V}_{\max }$ of $0.48 \mathrm{mg} / \mathrm{ml}$ and $0.014 \mu \mathrm{mol} / \mathrm{min}$ respectively (Figure 5) with a $K_{\text {cat }}$ of $0.029 \mathrm{~min}^{-1}$. Dixon-Webb's plot (Figure 6) for the determination of ionizable groups in the active site of the enzyme gave a $\mathrm{pKa}_{1}$ and $\mathrm{pKa}_{2}$ of 5.0 and 5.3 respectively with a calculated enthalpy of ionization of $0.047 \mathrm{kcal} / \mathrm{mol}$.

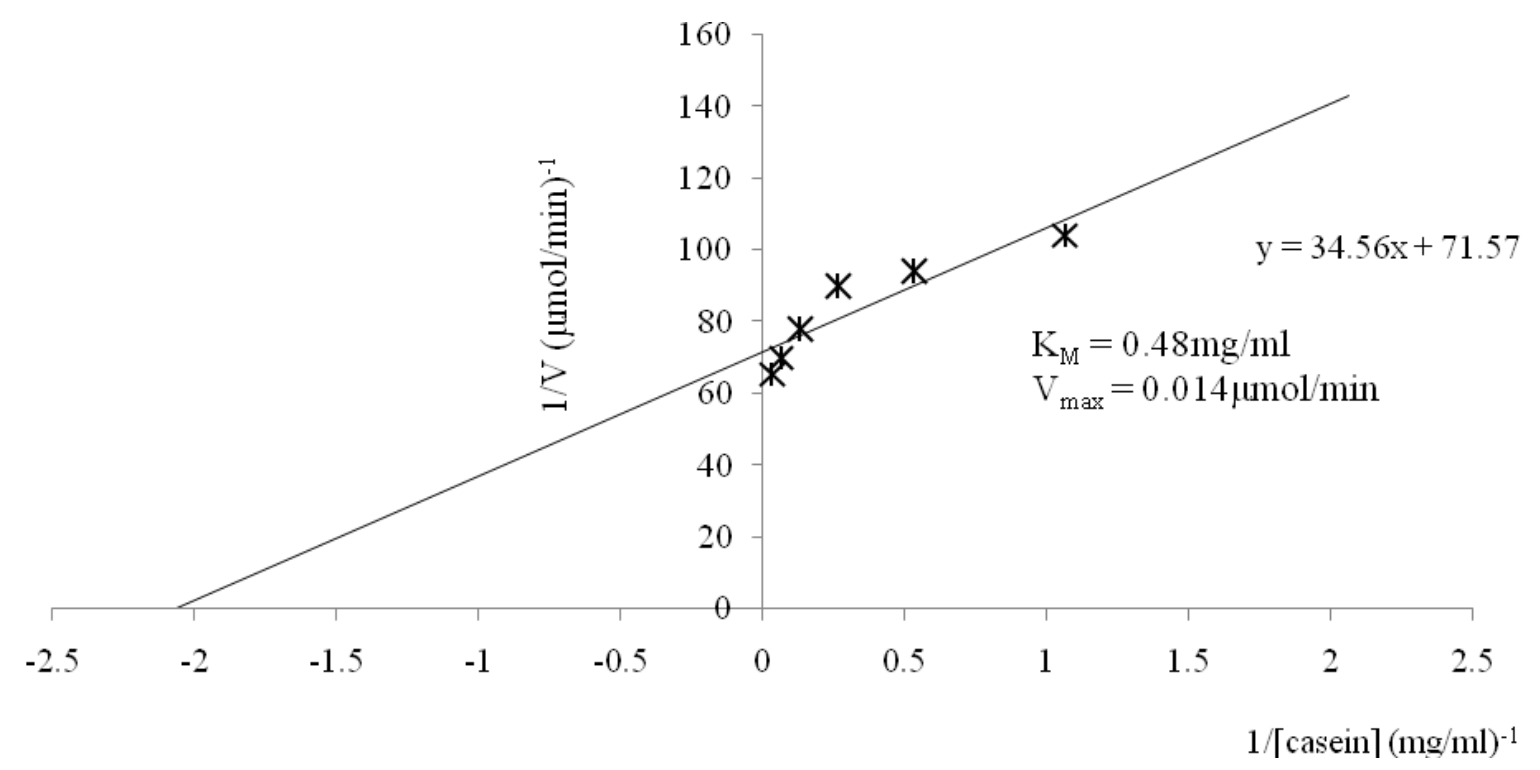

Figure 5. Lineweaver-Burke plot relating initial velocity data of the $J$. curcas protease with casein concentration. Each point represents an average of three experiments 


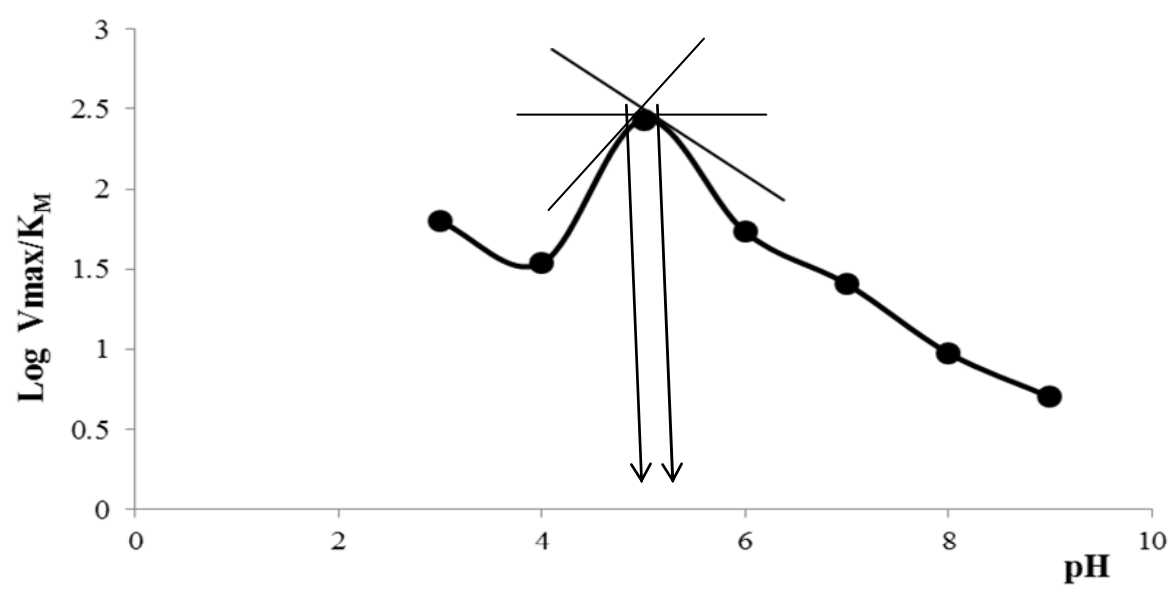

Figure 6. Dixon-Webb's plot for the determination of possible ionizable groups in the active site of J.curcas protease

Of the divalent cations tested on the protease, only $\mathrm{Ca}^{2+}, \mathrm{Mg}^{2+}$ and $\mathrm{Fe}^{2+}$ increased the activity whereas $\mathrm{Co}^{2+}, \mathrm{Zn}^{2+}$ and $\mathrm{Cu}^{2+}$ were inhibitory to the enzyme. The $J$. curcas protease was highly sensitive to a typical cysteine protease inhibitor, IAA while PT and EDTA were slightly inhibitory to the enzyme (Figure 7).

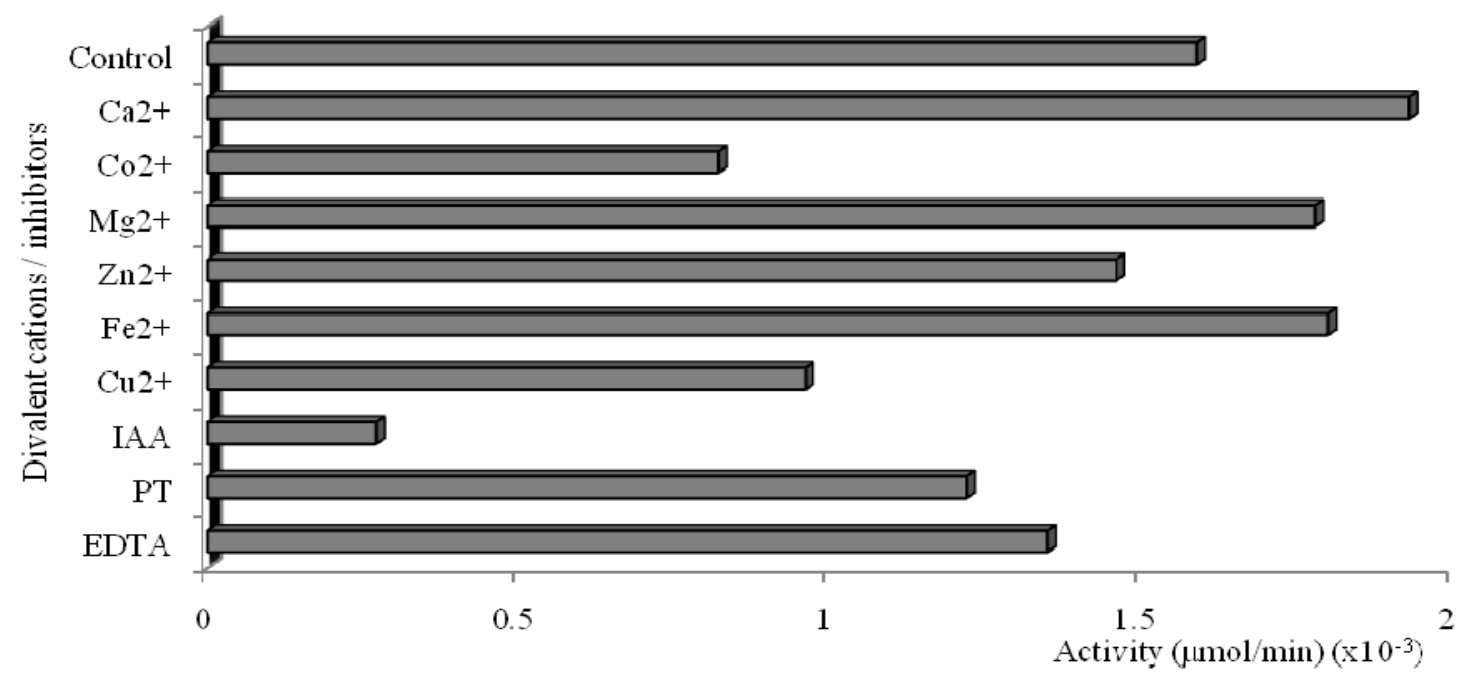

Figure 7. Effects of some divalent cations and inhibitors on the activity of $J$. curcas protease. IAA, PT and EDTA means iodoacetate, 1,10phenanthroline and ethylenediaminetetraacetate respectively.Each point represents the average of three experiments

\section{Discussion}

Understanding the characteristics of a candidate enzyme for industrial applications is a serious concern for industrial scientists, as it would help to establish the usefulness, or otherwise, of the enzyme in such processes. We report herein the partial characterization of protease from the leaves of $J$. curcas, a plant commonly used as live fence.

The $J$. curcas protease optimal activity at $\mathrm{pH} 4.0$ suggests that the enzyme would maximally hydrolyze proteins in acidic compartments. An acidic $\mathrm{pH}$ optimum region contributes to the enhancement of the enzymatic reaction by general acid catalytic mechanism.Optimum activity at acidic $\mathrm{pH}$ has been reported for both plantand microbial proteases (O'Donell et al., 2001; Ire et al., 2011) such as papain and bromelain used in industrial processes. Optimum temperature is an important factor for industrial enzymes selection because most industrial processes occur at slightly higher than physiological temperature. The enzyme had an optimum temperature of 
$45^{\circ} \mathrm{C}$ and was stable up to the same temperature in a thermostability studies. This observation is interesting because most industrial enzymes display optimum activity at $40-50^{\circ} \mathrm{C}$ (Devi, Banu, Gnanaprabhai, Pradeep, \& Palaiswamy, 2008; Ire et al., 2011). Moreover, the very low activation energy could imply that proteins degradation by J.curcas protease in an industrial process will be thermodynamically favorable because less frequency of collision will be required to surmount the activated complex and form the products. Both observations from the $\mathrm{pH}$ and temperature-activity relationships connote that the enzyme has the capacity to withstand the rigors of industrial applications such as food and brewing industries where these variables slightly differ with the physiological environment. On the other hand, it is possible that the $J$. curcas protease display these $\mathrm{pH}$ and temperature optima as an adaptational strategy to the extreme climatic and soil conditions that characterize $J$. curcas growth (Devappa, Makkar, \& Becker, 2011).

Proteases play a central role in the hydrolysis and mobilization of proteins with different three dimensional structures and therefore other natural proteins were tested as substrates for the $J$. curcas protease. It is noteworthy that all the proteins tested were hydrolyzed by the enzyme although with varying specificities. The observed $\mathrm{K}_{\mathrm{M}}$ and $\mathrm{V}_{\max }$ values are clear indications on the high kinetic efficiency of the enzyme. Previous studies on microbial proteases from Beauveria sp (Shankar, Rao, \& Laxman, 2011) and A. niger (Devi et al., 2008) reported a $\mathrm{K}_{\mathrm{M}}$ value of $5.1 \mathrm{mg} / \mathrm{ml}$ and $0.8 \mathrm{mg} / \mathrm{ml}$ respectively using casein as substrate. Cysteine protease from wheat Triticumaestivum had a $\mathrm{K}_{\mathrm{M}}$ of $2.8 \mathrm{mg} / \mathrm{ml}$ using azocasein as substrate (Fahmy et al., 2004) whereas wheat germ cysteine protease had a $K_{M}$ of $0.56 \mathrm{mg} / \mathrm{ml}$ using casein as substrate (Yang et al., 2011). It seems that the $K_{M}$ value of the $J$. curcas protease compares relatively less to other known microbial and plant proteases implying higher affinity of this enzyme for the substrates. Furthermore, the $\mathrm{K}_{\text {cat }}$ value of $0.029 \mathrm{~min}^{-1}$ indicates that about 1.78 casein molecules will be hydrolyzed to products per hour at saturation of the enzyme. This could further imply that the enzyme will be useful in industrial processes where the proteins degradation is required at moderate pace. The study of ionizable groups in the active site of $J$. curcas protease demonstrates the presence of groups with $\mathrm{pKa}_{1}$ and $\mathrm{pKa}_{2}$ of 5.0 and 5.3 respectively which suggests the presence of aspartic acid in and around the active site. The computed enthalpy of ionization is also within the range of beta carboxyl group of aspartic acid (Marangoni, 2003).

Divalent metal ions are involved in enzyme catalysis in a variety of ways which include activation of electrophiles or nucleophiles and bridging an enzyme with substrate together by means of coordinate bonds as well as holding reacting groups in the required three dimensional orientation (Advani, Mishra, Dubey, \& Thakur, 2010). $\mathrm{Ca}^{2+}, \mathrm{Mg}^{2+}$ and $\mathrm{Fe}^{2+}$ increased the enzymeactivity and considering the relative abundance of these cations in industrial processes, it suggests that the enzyme can easily be activated during the course of an industrial process. The observed effects of other divalent cations (analyzed herein), may suggest a probable modification of the enzyme protein conformation after binding in a different pattern (Ibrahim, Sallau, Salihu, \& Onwube, 2011) and hence causing a decrease in enzyme activity. This could further indicate that these divalent metal ions should be avoided during the exploitation of $J$. curcas protease in industrial activities. The protease lost a significant level of activity in the presence of IAA but slightly inhibited by EDTA and PT which suggests that a cysteine residue is involved in the catalytic mechanism. These observations could imply that the enzyme is a thiol (cysteine) protease but does not completely exclude other forms of proteases. Papain and bromelain used extensively in food industries are indeed cysteine proteases (Dubey, Pande, Singh, \& Jagannadham, 2007). Thus, the $J$. curcas protease could be of great potential in brewing industries and meat tenderization forthe removal of protein hazes.

Some of the prerequisites for the choice of industrial enzymes were investigated in this study and the $J$. curcas protease demonstrated some properties closely similar to other known industrial proteases and with exceptionally low activation energy.

\section{Acknowledgement}

Authors are grateful to Mr Shuaibu M. Bala of Institute of Agricultural Research, Ahmadu Bello University, Zaria for some technical assistance.

\section{References}

Advani, S., Mishra, P., Dubey, S., \& Thakur, S. (2010). Categoric prediction of metal ion mechanisms in the active sites of 17 select type II restriction endonucleases. Biochemistry and Biophysics Research Communication, 402, 177-179. http://dx.doi.org/10.1016/j.bbrc.2010.09.113

Capiralla, H., Hiroi, T., Hirokawa, T., \& Maeda, S, (2002). Purification and characterization of hydrophobic amino acid-specific endopeptidase from Halobactrium halobium S9 with potential applicationin debittering $\begin{array}{lllll}\text { of } \text { protein } \quad \text { hydrolysates. } & \text { Process }\end{array}$ 
http://dx.doi.org/10.1016/S0032-9592(02)00180-2

Cheng, K., Lu, F. P., Li, M., Liu, L. L., \& Liang, X. M. (2010). Purification and biochemical characterization of a serine alkaline protease TC4from a new isolated Bacillus alcalophilus TCCC11004 in detergent formulations. African Journal of Biotechnology, 9, 4942-4953.

Devappa, R. K., Makkar, H. P. S., \& Becker, K. (2011). Jatropha Diterpenes: a Review. Journal of American Oil Chemical Society, 88, 301-22.

Devi, M. K., Banu, A. R., Gnanaprabhal, G. R., Pradeep, B. V., \& Palaniswamy, M. (2008). Purification, characterization of alkaline protease enzyme from native isolate Aspergillus niger and its compatibility with commercial detergents. Indian Journal of Science and Technology, 1, 1-6.

Dubey, V. K., Pande, M., Singh, B. K., \& Jagannadham, M. V. (2007). Papain-like proteases: Applications of their inhibitors. African Journal of Biotechnology, 6, 1077-1086.

Fahmy, A. S., Ali, A. A., \& Mohamed, S. A. (2004). Characterization of a cysteineprotease from wheat Triticum aestivum(cv. Giza 164). Bioresource Technology, 91, 297-304

Gubitz, G. M., Lischnig, T., Stebbing, D., \& Saddler, J. N. (1997). Enzymatic removal of hemicelluloses from dissolving pulps. Biotechnology Letters, 19, 491-495.

Gupta, R., Beg, Q. K., \& Lorenz, P. (2002). Bacterial alkaline proteases: molecular approaches and industrial applications. Applied Microbiology and Biotechnology, 59, 15-32.

Ibrahim, M. A., Sallau, A. B., Salihu, A., \& Onwube, K. C. (2011). Partial characterization of phospholipase $\mathrm{A}_{2}$ from the .erythrocytic stage of Plasmodium berghei. Asian Journal of Biochemistry, 6, 208-213.

Ire, F. S., Okolo, B. M., \& Moneke, A. A. (2011). Purification and characterization of an acid protease from Aspergillus carbonarius. African Journal of Food Sciences, 5, 695-709.

Kaneda, M., Yonezawa, H., \& Uchikoba, T. (1997). Purification and some properties of protease from the sarcocarp of musk melon. Biosciences, Biotechnology and Biochemistry, 61, 2100-2102.

Li, C., Cao, X., Gu, Z., \& Wen, H. (2011). A preliminary study of the protease activities in germinating brown rice (Oryza sativa L.). Journal of the Science of Food and Agriculture, 91, 915-920.

Marangoni, A. G. (2003). Enzyme kinetics, pH dependence of enzyme catalysed reactions. John Wiley, New Jersey, pp. 79-84.

O’Donnell, D., Wang, L., Xu, J., Ridgway, D., Gu, T., \& Moo-Young, M. (2001). Enhanced heterologous protein production in Aspergillus niger through $\mathrm{pH}$ control of extracellular protease activity. Biochemical Engineering Journal, 8, 187-193.

Shankar, S., Rao, M., \& Laxman, R. S. (2011). Purification and characterization of an alkaline protease by a new strain of Beauveria sp. Process Biochemistry, 46, 579-585. http://dx.doi.org/10.1016/j.procbio.2010.10.013

Soares, V. F., Castilho, L. R., Bon, E. P., \& Freire, D. M. (2005). High-yield Bacillus subtilis protease production by solid-state fermentation. Applied Biochemistry and Biotechnology, 121, 311-319.

Subramani, T. Chandrashekharaiah, K. S., Swamy, N. R., \& Murthy, S. K. R. (2012). Purification and characterization of carboxylesterase from the seeds of Jatropha curcas. Protein Journal, 31, 120-128.

Tang, X. M., Lakay, F. M., Shen, W., Shao, W., Fang, H., Prior, B. A., Wang, Z., \& Zhuge, J. (2004). Purification and characterization of an alkaline protease used in tannery industry from Bacillus licheniformis. Biotechnology letters, 26, 1421-1424.

Tunga, R., Shrivastava, B., \& Banerjee, R. (2003).Purification and characterization of a protease from solid state cultures of Aspergillus parasiticus. Process Biochemistry, 38, 1553-1558. http://dx.doi.org/10.1016/S0032-9592(03)00048-7

Yang, R., Song, J., Gu, Z., \& Li, C. (2011). Partial purification and characterization of cysteine protease in wheat germ. Journal of the Science of Food and Agriculture, 91, 2437-2442. 